\title{
The Oxidation of 2,4,6-Trinitrotoluene with an Ozone-Oxygen Mixture: A Simple Method for Preparation of 1,3,5-Trinitrobenzene
}

\author{
Mohammad Ali Zarei, ${ }^{1}$ Hasan Tahermansouri, ${ }^{2}$ and Yadollah Bayat ${ }^{1}$ \\ ${ }^{1}$ Department of Chemistry and Engineering Chemistry, Malek Ashtar University of Technology, P.O. Box 16765-3454, Tehran, Iran \\ ${ }^{2}$ Department of Chemistry, Ayatollah Amoli Branch, Islamic Azad University, P.O. Box 678, Amol, Iran
}

Correspondence should be addressed to Mohammad Ali Zarei; mazmm84@yahoo.com

Received 9 May 2013; Revised 29 June 2013; Accepted 9 July 2013

Academic Editor: Chengshuai Liu

Copyright ( $) 2013$ Mohammad Ali Zarei et al. This is an open access article distributed under the Creative Commons Attribution License, which permits unrestricted use, distribution, and reproduction in any medium, provided the original work is properly cited.

\begin{abstract}
The oxidation of 2,4,6-trinitrotoluene (TNT) to 1,3,5-trinitrobenzene (TNB) in one step, 2,4,6-trinitrobenzoic acid (TNBA), and 2,4,6-trinitrobenzaldehyde (TNBAl) with an ozone-oxygen mixture in different solvents, catalysts, and temperatures has been investigated. Reducing the number of steps in the oxidation of TNT to TNB is the major advantage of this procedure with respect to conventional processes such as chromic acid and potassium permanganate. The oxidation of TNT to TNB was completed in one step as compared to two steps in the conventional approach. The products were obtained with relatively good yield.
\end{abstract}

\section{Introduction}

1,3,5-Trinitrobenzene (TNB) is an explosive compound with slightly greater explosive force than 2,4,6-trinitrotoluene (TNT) [1]. TNB is used primarily as a high explosive for commercial mining and military use. Also, it has been employed as an agent to vulcanize natural rubber [2] and as a mediating agent to mediate the synthesis of other explosive compounds [3].

So far, the different methods for preparation of TNB were reported [4-8]. The most common method is the oxidation of TNT to TNB using oxidants such as chromic acid, potassium permanganate in acid, basic, and neutral solutions, nitric acid, and silver oxide in which these methods are not attractive because they produce the large amounts of toxic and difficultly utilizable wastes. On the other hand, direct nitration of benzene requires such harsh conditions whose yields are poor, and purification of TNB is very difficult. Even the use of modern catalysts such as lanthanide nitrates does not alleviate this problem [9].

In this paper, we investigated the one-step oxidation of TNT with an ozone-oxygen mixture in presence of the different conditions such as catalyst, temperature, and oxidative agents (Table 1). In addition, this method can be used to develop a low-waste process for TNB production. Also, this reaction is carried out with 2,4-dinitrotoluene (DNT) to prove the generality of this procedure (Table 2 ). The obtained results approximately were similar to each other. Synthesis route of the reactions is shown in Figure 1.

\section{Experimental}

Materials were purchased from Merck and Fluka companies. ${ }^{1}$ HNMR spectra were recorded with a Bruker DRX-300 Avance instrument using $\mathrm{CDCl}_{3}$ as the deuterated solvent containing tetramethylsilane as internal standard, at $300, \delta$ in parts per million, and $\mathrm{J}$ in hertz. The experiments were carried out with a Compact Ozone Generator (OZONEUF, model: COG $10 \mathrm{~S})$. Elemental analyses $(\mathrm{C}, \mathrm{H}$, and $\mathrm{N})$ were obtained with a Heraeus $\mathrm{CHN}-\mathrm{O}-$ Rapid analyzer.

2.1. Typical Procedure without Hydrogen Peroxide. TNT or DNT was oxidized in a round-bottom flask $(100 \mathrm{~mL})$ with a fine-pore barrier for dispersion of the gas mixture. The reactor was charged with TNT or DNT $(4 \mathrm{mmol})$, catalyst $(1 \mathrm{mmol}), \mathrm{KBr}(0.1 \mathrm{~g})$, and $40 \mathrm{~mL}$ of glacial acetic acid 
TABLE 1: The conditions and results of the oxidation of TNT.

\begin{tabular}{|c|c|c|c|c|c|c|c|c|}
\hline Entry $^{2}$ & Solvent & $\mathrm{Co}(\mathrm{OAc})_{2} \cdot 4 \mathrm{H}_{2} \mathrm{O}$ & Temperature $\left({ }^{\circ} \mathrm{C}\right)$ & $\mathrm{Co}\left(\mathrm{NO}_{3}\right)_{2} \cdot 6 \mathrm{H}_{2} \mathrm{O}$ & $\mathrm{H}_{2} \mathrm{O}_{2}(\% 30)$ & $\% \mathrm{TNBAl}$ & $\%$ TNBA & $\% \mathrm{TNB}$ \\
\hline 1 & $\mathrm{CH}_{3} \mathrm{COOH}$ & $1 \mathrm{mmol}$ & 40 & & & 10 & 0 & 0 \\
\hline 2 & $\mathrm{CH}_{3} \mathrm{COOH}$ & $1 \mathrm{mmol}$ & 100 & & & 60 & 0 & 0 \\
\hline 3 & $\mathrm{CH}_{3} \mathrm{COOH}$ & $1 \mathrm{mmol}$ & 40 & & $20 \mathrm{~mL}$ & 27 & 0 & 0 \\
\hline 4 & $\mathrm{CH}_{3} \mathrm{COOH}$ & $1 \mathrm{mmol}$ & 100 & & $20 \mathrm{~mL}$ & 68 & 23 & 0 \\
\hline 5 & $\mathrm{HCOOH}$ & $1 \mathrm{mmol}$ & 40 & & & 23 & 0 & 0 \\
\hline 6 & $\mathrm{HCOOH}$ & $1 \mathrm{mmol}$ & 100 & & & 45 & 36 & 0 \\
\hline 7 & $\mathrm{HCOOH}$ & $1 \mathrm{mmol}$ & 40 & & $20 \mathrm{~mL}$ & 40 & 15 & 35 \\
\hline 8 & $\mathrm{HCOOH}$ & $1 \mathrm{mmol}$ & 100 & & $20 \mathrm{~mL}$ & 15 & 0 & 74 \\
\hline 9 & $\mathrm{CH}_{3} \mathrm{COOH}$ & & 40 & $1 \mathrm{mmol}$ & & 12 & 0 & 0 \\
\hline 10 & $\mathrm{CH}_{3} \mathrm{COOH}$ & & 100 & $1 \mathrm{mmol}$ & & 57 & 0 & 0 \\
\hline 11 & $\mathrm{CH}_{3} \mathrm{COOH}$ & & 40 & $1 \mathrm{mmol}$ & $20 \mathrm{~mL}$ & 28 & 0 & 0 \\
\hline 12 & $\mathrm{CH}_{3} \mathrm{COOH}$ & & 100 & $1 \mathrm{mmol}$ & $20 \mathrm{~mL}$ & 60 & 30 & 0 \\
\hline 13 & $\mathrm{HCOOH}$ & & 40 & $1 \mathrm{mmol}$ & & 18 & 0 & 0 \\
\hline 14 & $\mathrm{HCOOH}$ & & 100 & $1 \mathrm{mmol}$ & & 53 & 32 & 0 \\
\hline 15 & $\mathrm{HCOOH}$ & & 40 & $1 \mathrm{mmol}$ & $20 \mathrm{~mL}$ & 34 & 21 & 18 \\
\hline 16 & $\mathrm{HCOOH}$ & & 100 & $1 \mathrm{mmol}$ & $20 \mathrm{~mL}$ & 24 & 5 & 65 \\
\hline
\end{tabular}

${ }^{2}$ The time of ozonolysis for all reactions was $6 \mathrm{~h}$.

TABLE 2: The conditions and results of the oxidation of DNT.

\begin{tabular}{|c|c|c|c|c|c|c|c|c|}
\hline Entry $^{3}$ & Solvent & $\mathrm{Co}(\mathrm{OAc})_{2} \cdot 4 \mathrm{H}_{2} \mathrm{O}$ & Temperature $\left({ }^{\circ} \mathrm{C}\right)$ & $\mathrm{Co}\left(\mathrm{NO}_{3}\right)_{2} \cdot 6 \mathrm{H}_{2} \mathrm{O}$ & $\mathrm{H}_{2} \mathrm{O}_{2}(\% 30)$ & $\%$ DNBAl & $\%$ DNBA & $\% \mathrm{DNB}$ \\
\hline 1 & $\mathrm{CH}_{3} \mathrm{COOH}$ & $1 \mathrm{mmol}$ & 40 & & & 27 & 0 & 0 \\
\hline 2 & $\mathrm{CH}_{3} \mathrm{COOH}$ & $1 \mathrm{mmol}$ & 100 & & & 74 & 0 & 0 \\
\hline 3 & $\mathrm{CH}_{3} \mathrm{COOH}$ & $1 \mathrm{mmol}$ & 40 & & $20 \mathrm{~mL}$ & 45 & 0 & 0 \\
\hline 4 & $\mathrm{CH}_{3} \mathrm{COOH}$ & $1 \mathrm{mmol}$ & 100 & & $20 \mathrm{~mL}$ & 73 & 18 & 0 \\
\hline 5 & $\mathrm{HCOOH}$ & $1 \mathrm{mmol}$ & 40 & & & 31 & 0 & 0 \\
\hline 6 & $\mathrm{HCOOH}$ & $1 \mathrm{mmol}$ & 100 & & & 28 & 57 & 0 \\
\hline 7 & $\mathrm{HCOOH}$ & $1 \mathrm{mmol}$ & 40 & & $20 \mathrm{~mL}$ & 29 & 21 & 38 \\
\hline 8 & $\mathrm{HCOOH}$ & $1 \mathrm{mmol}$ & 100 & & $20 \mathrm{~mL}$ & 0 & 12 & 86 \\
\hline 9 & $\mathrm{CH}_{3} \mathrm{COOH}$ & & 40 & $1 \mathrm{mmol}$ & & 34 & 0 & 0 \\
\hline 10 & $\mathrm{CH}_{3} \mathrm{COOH}$ & & 100 & $1 \mathrm{mmol}$ & & 66 & 0 & 0 \\
\hline 11 & $\mathrm{CH}_{3} \mathrm{COOH}$ & & 40 & $1 \mathrm{mmol}$ & $20 \mathrm{~mL}$ & 43 & 0 & 0 \\
\hline 12 & $\mathrm{CH}_{3} \mathrm{COOH}$ & & 100 & $1 \mathrm{mmol}$ & $20 \mathrm{~mL}$ & 51 & 43 & 0 \\
\hline 13 & $\mathrm{HCOOH}$ & & 40 & $1 \mathrm{mmol}$ & & 32 & 0 & 0 \\
\hline 14 & $\mathrm{HCOOH}$ & & 100 & $1 \mathrm{mmol}$ & & 26 & 51 & 0 \\
\hline 15 & $\mathrm{HCOOH}$ & & 40 & $1 \mathrm{mmol}$ & $20 \mathrm{~mL}$ & 31 & 25 & 42 \\
\hline 16 & $\mathrm{HCOOH}$ & & 100 & $1 \mathrm{mmol}$ & $20 \mathrm{~mL}$ & 0 & 16 & 73 \\
\hline
\end{tabular}

${ }^{3}$ The time of ozonolysis for all reactions was $6 \mathrm{~h}$.<smiles>[X]c1cc([N+](=O)[O-])cc([N+](=O)[O-])c1</smiles>

FIGURE 1: Synthesis route of DNT and TNT oxidation. Only the major product is shown. 
or formic acid. Then it was stirred and heated to the required temperature, and an ozone-oxygen mixture was fed for $6 \mathrm{~h}$. Afterwards, the mixture of reaction is mixed with $500 \mathrm{~g}$ of crushed ice. Then the produced precipitation was purified by column chromatography $\left(\mathrm{SiO}_{2} ; \mathrm{n}\right.$-hexane/AcOEt $\left.=5 / 1\right)$ to afford the pure adducts.

2.2. Typical Procedure with Hydrogen Peroxide. TNT or DNT was oxidized in a round-bottom flask $(100 \mathrm{~mL})$ with a finepore barrier for dispersion of the gas mixture. The reactor was charged with TNT or DNT (4 mmol), catalyst ( $1 \mathrm{mmol})$, $\mathrm{KBr}(0.1 \mathrm{~g}), 40 \mathrm{~mL}$ of glacial acetic or formic acid, and $10 \mathrm{~mL}$ $\left(\mathrm{H}_{2} \mathrm{O}_{2} \% 30\right)$. Then it was stirred and heated to the required temperature, and an ozone-oxygen mixture was fed. After $2 \mathrm{~h}$ ozonolysis, $10 \mathrm{~mL} \mathrm{H}_{2} \mathrm{O}_{2}$ again was added to the mixture of reaction. Afterwards, the mixture of reaction is mixed with $500 \mathrm{~g}$ of crushed ice. Then the produced precipitation was purified by column chromatography $\left(\mathrm{SiO}_{2} ; \mathrm{n}\right.$-hexane/ AcOEt $=5 / 1)$ to afford the pure adducts.

\section{Data}

2,4,6-Trinitrobenzaldehyde. Yield: 68\%, yellow powder, mp $119^{\circ} \mathrm{C}$ [lit. [10] $\mathrm{mp} 119^{\circ} \mathrm{C}$ ]. IR $(\mathrm{KBr})\left(v_{\max }=\mathrm{cm}^{-1}\right): 3092(\mathrm{CH})$, 2859 ( $\mathrm{CH}$ aldehyde), $1696(\mathrm{C}=\mathrm{O}), 1587(\mathrm{C}=\mathrm{C}), 1529$ and 1349 $\left(\mathrm{NO}_{2}\right)$. Anal. Calcd. for $\mathrm{C}_{7} \mathrm{H}_{3} \mathrm{~N}_{3} \mathrm{O}_{7}(241.00)$ : $\mathrm{C}, 34.87 ; \mathrm{H}, 1.25$; $\mathrm{N}, 17.43$; Found: C, 34.6; H, 1.2; N , 17.5. ${ }^{1} \mathrm{H}$ NMR $(300 \mathrm{MHz}$, $\left.\mathrm{CDCl}_{3}\right): 8.85(\mathrm{~s}, 2 \mathrm{H}), 10.33(\mathrm{~s}, 1 \mathrm{H})$.

2,4,6-Trinitrobenzoic Acid. Yield: 36\%, yellow powder, mp $229^{\circ} \mathrm{C}$. IR $(\mathrm{KBr})\left(\nu_{\max }=\mathrm{cm}^{-1}\right)$ : $3110(\mathrm{OH}), 3086(\mathrm{CH}), 1712$ $(\mathrm{C}=\mathrm{O}), 1609(\mathrm{C}=\mathrm{C}), 1549$ and $1369\left(\mathrm{NO}_{2}\right)$. Anal. Calcd. for $\mathrm{C}_{7} \mathrm{H}_{3} \mathrm{~N}_{3} \mathrm{O}_{7}$ (256.99): C, 32.70; H, 1.18; N, 16.34; Found: C, $32.8 ; \mathrm{H}, 1.1 ; \mathrm{N}, 16.6 .{ }^{1} \mathrm{H}$ NMR $\left(300 \mathrm{MHz}, \mathrm{CDCl}_{3}\right): 9.13$ (s, 2H), $11.1(\mathrm{~s}, 1 \mathrm{H})$.

1,3,5-Trinitrobenzene. Yield: 74\%, yellow sludgy powder, mp $123^{\circ} \mathrm{C}\left[\right.$ lit. $\left.[4,11,12] \mathrm{mp} 121-122^{\circ} \mathrm{C}\right]$. IR $(\mathrm{KBr})\left(\nu_{\max }=\mathrm{cm}^{-1}\right)$ : $3107(\mathrm{CH}), 1623(\mathrm{C}=\mathrm{C}), 1544$ and $1345\left(\mathrm{NO}_{2}\right)$. Anal. Calcd. for $\mathrm{C}_{6} \mathrm{H}_{3} \mathrm{~N}_{3} \mathrm{O}_{6}$ (213.00): C, 33.82; H, 1.42; N, 19.72; Found: C, 33.6; $\mathrm{H}, 1.5 ; \mathrm{N}, 19.9 .{ }^{1} \mathrm{H}$ NMR $\left(300 \mathrm{MHz}, \mathrm{CD}_{3} \mathrm{COCD}_{3}\right): 9.33$ $(\mathrm{s}, 3 \mathrm{H})$.

2,4-Dinitrobenzaldehyde. Yield: $73 \%$, yellow crystal, $\mathrm{mp} 73^{\circ} \mathrm{C}$ [lit. $\left.[10,13] \mathrm{mp} 69-72^{\circ} \mathrm{C}\right]$. IR $(\mathrm{KBr})\left(v_{\max }=\mathrm{cm}^{-1}\right): 3111(\mathrm{CH})$, $2877(\mathrm{CH}$ aldehyde), $1701(\mathrm{C}=\mathrm{O}), 1601(\mathrm{C}=\mathrm{C}), 1537$ and 1360 $\left(\mathrm{NO}_{2}\right)$. Anal. Calcd. for $\mathrm{C}_{7} \mathrm{H}_{4} \mathrm{~N}_{2} \mathrm{O}_{5}$ (196.12): C, 42.87; H, 2.06; N, 14.28; Found: C, 42.6; H, 2.02; N 14.15. ${ }^{1} \mathrm{H}$ NMR $(300 \mathrm{MHz}$, $\mathrm{CDCl}_{3}$ ): $8.34(\mathrm{~s}, 1 \mathrm{H}), 8.14(\mathrm{~d}, 1 \mathrm{H}), 8.03(\mathrm{~d}, 1 \mathrm{H}), 10.32(\mathrm{~s}, 1 \mathrm{H})$.

2,4-Dinitrobenzoic Acid. Yield: 57\%, yellow crystals, mp $181^{\circ} \mathrm{C}$ [lit. [14] mp 182-183 ${ }^{\circ} \mathrm{C}$ ]. IR (KBr) $\left(\nu_{\max }=\mathrm{cm}^{-1}\right): 3122$ $(\mathrm{OH}), 3084(\mathrm{CH}), 1724(\mathrm{C}=\mathrm{O}), 1620(\mathrm{C}=\mathrm{C}), 1544$ and 1356 $\left(\mathrm{NO}_{2}\right)$. Anal. Calcd. for $\mathrm{C}_{7} \mathrm{H}_{4} \mathrm{~N}_{2} \mathrm{O}_{6}(212.12)$ : $\mathrm{C}, 39.64 ; \mathrm{H}, 1.90$; $\mathrm{N}, 13.21$; Found: C, 39.5; H, 1.8; N, 13.4. ${ }^{1} \mathrm{H}$ NMR $(300 \mathrm{MHz}$, $\left.\mathrm{CDCl}_{3}\right): 8.65(\mathrm{~d}, 1 \mathrm{H}), 8.48(\mathrm{dd}), 8.06(\mathrm{~d}, 1 \mathrm{H}), 10.8(\mathrm{~s}, 1 \mathrm{H})$.

1,3-Dinitrobenzene. Yield: $86 \%$, yellow powder, $\mathrm{mp} 91^{\circ} \mathrm{C}$ [lit. [12] $\left.\mathrm{mp} 89-90^{\circ} \mathrm{C}\right]$. IR $(\mathrm{KBr})\left(v_{\max }=\mathrm{cm}^{-1}\right): 3110(\mathrm{CH}), 1615$
$(\mathrm{C}=\mathrm{C}), 1538$ and $1364\left(\mathrm{NO}_{2}\right)$. Anal. Calcd. for $\mathrm{C}_{6} \mathrm{H}_{4} \mathrm{~N}_{2} \mathrm{O}_{4}$ (168.11): C, 42.87; H, 2.40; N, 16.66; Found: C, 42.7; H, 2.3; $\mathrm{N}, 16.4 .{ }^{1} \mathrm{H}$ NMR $\left(300 \mathrm{MHz}, \mathrm{CDCl}_{3}\right): 8.79(\mathrm{t}, 1 \mathrm{H}), 8.62(\mathrm{dd}$, $2 \mathrm{H}), 7.96(\mathrm{t}, 1 \mathrm{H})$.

\section{Results and Discussion}

According to Table 1 , the reaction of ozone with TNT in different conditions leads to the diverse products such as TNBAl, TNBA, and TNB. As it is observed, the temperature plays an important role in the ozonolysis reaction. At $40^{\circ} \mathrm{C}$, the reaction of ozone with TNT in presence of $\mathrm{Co}(\mathrm{OAc})_{2}$ was slow, and the conversion reached $10 \%$ after 6 hours (entry 1 ). At $100^{\circ} \mathrm{C}$, TNBAl yield based on the reacted substrate reaches $60 \%$ (entry 2). Also, it is characterized that if the time and temperature of ozonolysis increase $\left(12 \mathrm{~h}, 100^{\circ} \mathrm{C}\right)$, the reaction yield reaches $0 \%$. This shows that the reaction with cleavage of aromatic ring forwarded which could be degraded gradually into final products such as aliphatic organic acids, water, and carbon dioxide $[15,16]$. The addition of hydrogen peroxide to pervious reactions causes acceleration of the oxidation and the increase of yield at $100^{\circ} \mathrm{C}$ (TNBAl $68 \%$ and TNBA 23\%). When the reaction is carried out in formic acid and hydrogen peroxide, the obtained results were remarkable. At $100^{\circ} \mathrm{C}$, TNB as the major product (\%74) obtained which it is the favorable method for synthesis this compound. Also, according to Table 1 , the obtained results with $\mathrm{Co}\left(\mathrm{NO}_{3}\right)_{2}$ almost were similar to $\mathrm{Co}(\mathrm{OAc})_{2}$ (entries 9-16). On the other hand, the oxidation of DNT is carried out to prove the generality of this method. According to Table 2, it could be found that the results approximately are the same to TNT oxidation which confirms this efficient procedure for other substituted toluenes.

Only, the mechanism which we have suggested to correlate all the results of this work involves the presence of the free radicals of hydroxyl and perhydroxyl as intermediates in these homogeneous reactions. A plausible mechanism for the formation of products is shown in Figure 2. Under the experimental conditions, ozone oxidizes mainly $\mathrm{Co}^{2+}$ to reactive $\mathrm{Co}^{3+}$ species (1) which rapidly and selectively oxidize the methyl group of aryl (2). In the presence of $\mathrm{H}_{2} \mathrm{O}_{2}$, after the ozone undergoes a catalytic decomposition by $\mathrm{Co}^{+2}$, the mixture of $\mathrm{Co}^{+3}$ and ozone is added to hydrogen peroxide in which the reaction between $\mathrm{Co}^{+3}$ and hydrogen peroxide induces a decomposition of ozone by reactions (4) and (5). The produced free radicals, hydroxyl and perhydroxyl ones, will start a chain decomposition by reactions (4) and (5). The presence of these radicals previously has been reported $[17,18]$. Then, the produced benzyl radical $(2,6)$ is attacked by $\mathrm{O}_{2}$ to produce peroxide and aldehyde. Also, the subsequent reaction with ozone or hydrogen peroxide results in TNBA or TNB.

Introduction of potassium bromide into the reaction mixture substantially accelerates the oxidation with an ozoneoxygen mixture [19]. The suggested mechanism is that potassium bromide reacts with cobalt (II) to form $\mathrm{Co}^{2+} \mathrm{Br}^{*}$ in which this complex is more reactive than $\mathrm{Co}^{3+}$ and oxidizes TNT by the reaction shown in Figure 3. 

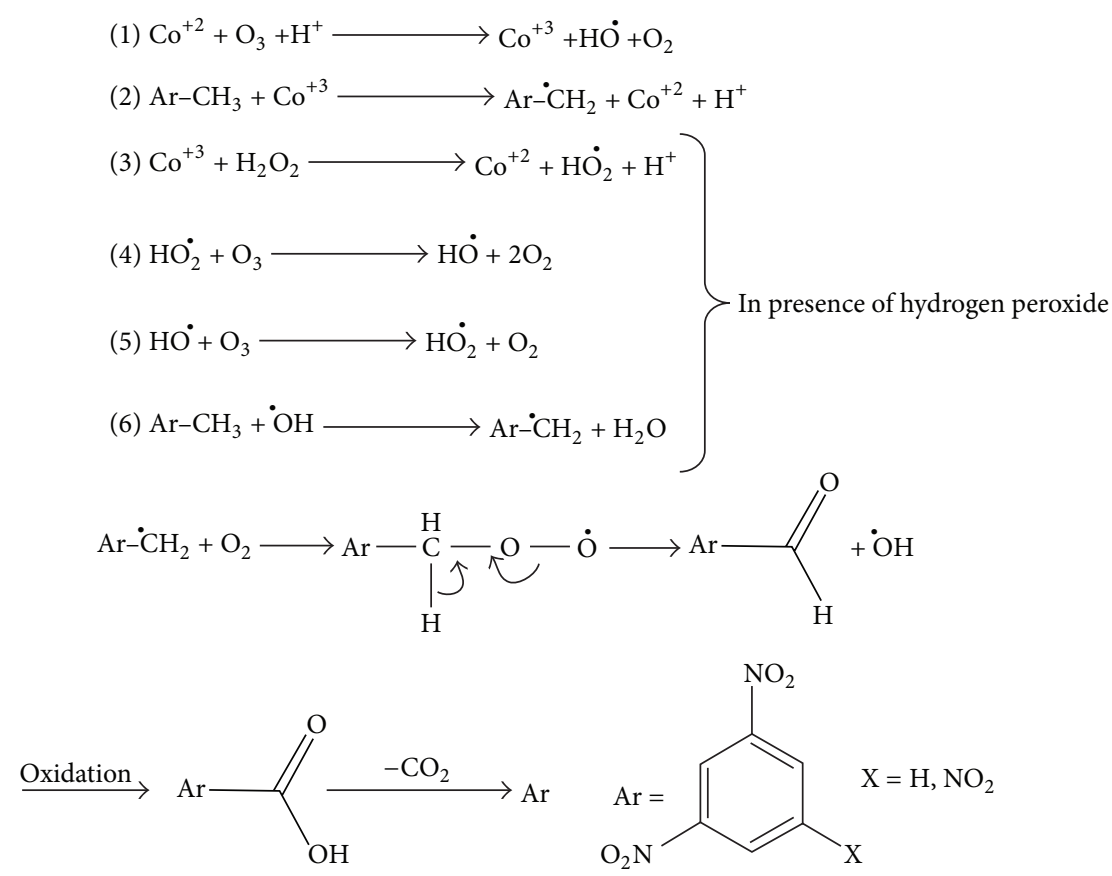<smiles>[X]c1cc([N+](=O)[O-])cc([N+](=O)[O-])c1</smiles>

FIGURE 2: Plausible mechanism for the formation of products.

$\mathrm{Ar}-\mathrm{CH}_{3}+\mathrm{Co}^{+2} \mathrm{Br} \longrightarrow \mathrm{Ar}-\dot{\mathrm{C}} \mathrm{H}_{2}+\mathrm{Co}^{+3} \mathrm{Br}^{-}+\mathrm{H}^{+}$

FIGURE 3

\section{Conclusion}

The yields of TNB and DNB in this procedure were obtained as $74 \%$ and $86 \%$, respectively. Also, this method can be used to produce TNB and DNB for applied future.

\section{References}

[1] F. Volk and H. Bathelt, "Performance parameters of explosives: equilibrium and non-equilibrium reactions," Propellants, Explosives, Pyrotechnics, vol. 27, p. 141, 2002.

[2] J. T. Blake, "Studies in the vulcanization of rubber. IIvulcanization of rubber with nitro compounds," Rubber Chemistry and Technology, vol. 3, pp. 639-650, 1930.

[3] H. Cruz, I. Gallardo, and G. Guirado, "Electrochemical synthesis of organophosphorus compounds through nucleophilic aromatic substitution: mechanistic investigations and synthetic scope," European Journal of Organic Chemistry, no. 36, pp. 73787389, 2011.

[4] J. C. Bottaro, R. Malhotra, and A. Dodge, "A facile two-step synthesis of 1,3,5-trinitrobenzene," Synthesis, no. 4, pp. 499-500, 2004.

[5] H. Gilman and A. H. Blatt, Organic Synthesis Collective, vol. 1, John Wiley \& Sons, New York, NY, USA, 1941.

[6] G. A. Olah and H. C. Lin, "Synthetic methods and reactions. XI. Convenient direct preparation of 1,3,5-trinitrobenzene from $\mathrm{m}$ dinitrobenzene by nitration with nitronium tetrafluoroborate in fluorosulfuricacid solution," Synthesis, vol. 1974, no. 6, pp. 444445, 1974.
[7] B. O. Baeckman, E. Bengtsson, N. Billingsson, and K. J. Persson, "1,3,5-Trinitrobenzene," Chemical Abstracts, vol. 95, p. 24518, 1981, German Offenlegungsschrift DE3035030.

[8] R. L. Atkins, A. T. Nielsen, C. Bergens, and W. S. Wilson, "Synthesis of polynitrobenzenes. Oxidation of polynitroanilines and their N-hydroxy, N-methoxy, and N-Acetyl derivatives," Journal of Organic Chemistry, vol. 49, no. 3, pp. 503-507, 1984.

[9] J. H. Forsberg, V. T. Spaziano, T. M. Balasubramanian et al., "Use of lanthanide(III) ions as catalysts for the reactions of amines with nitriles," Journal of Organic Chemistry, vol. 52, no. 6, pp. 1017-1021, 1987.

[10] T. Kawakami and H. Suzuki, "Masked acylation of m-Dinitrobenzene and deriviatives with nitroalkanes under basic conditions: Nitromethylation and $\alpha$-(hydroxyimino)alkylation," Tetrahedron Letters, vol. 40, no. 6, pp. 1157-1160, 1999.

[11] R. C. Weast, Handbook of Chemistry and Physics, Chemical Rubber Company, Cleveland, Ohio, USA, 1970.

[12] R. W. Murray, S. N. Rajadhyaksha, and L. Mohan, "Oxidation of primary amines by dimethyldioxirane," Journal of Organic Chemistry, vol. 54, no. 24, pp. 5783-5788, 1989.

[13] S.-X. Wang, Z.-C. Tan, Q. Shi et al., "Calorimetric study and thermal analysis of crystalline 2,4-dinitrobenzaldehyde $\left(\mathrm{C}_{7} \mathrm{H}_{4} \mathrm{~N}_{2} \mathrm{O}_{5}\right)$," Journal of Chemical Thermodynamics, vol. 37, no. 4, pp. 349-355, 2005.

[14] P. Segura, J. F. Bunnett, and L. Villanova, "Substituent effects on the decarboxylation of dinitrobenzoate ions, representative aromatic SE1 reactions," Journal of Organic Chemistry, vol. 50, no. 7, pp. 1041-1045, 1985.

[15] W.-S. Chen, C.-N. Juan, and K.-M. Wei, "Decomposition of dinitrotoluene isomers and 2,4,6-trinitrotoluene in spent acid from toluene nitration process by ozonation and photoozonation," Journal of Hazardous Materials, vol. 147, no. 1-2, pp. 97-104, 2007. 
[16] M.-J. Liou, M.-C. Lu, and J.-N. Chen, "Oxidation of explosives by Fenton and photo-Fenton processes," Water Research, vol. 37, no. 13, pp. 3172-3179, 2003.

[17] H. Taube and W. C. Bray, "Chain reactions in aqueous solutions containing ozone, hydrogen peroxide and acid," Journal of the American Chemical Society, vol. 62, no. 12, pp. 3357-3373, 1940.

[18] B. Utset, J. Garcia, J. Casado, X. Domènech, and J. Peral, "Replacement of $\mathrm{H}_{2} \mathrm{O}_{2}$ by $\mathrm{O}_{2}$ in Fenton and photo-Fenton reactions," Chemosphere, vol. 41, no. 8, pp. 1187-1192, 2000.

[19] P. Y. Andreev, G. A. Galstyan, A. G. Galstyan, and I. S. Yakunina, "Oxidation of 2,4-dinitrotoluene with an ozone-oxygen mixture," Russian Journal of Applied Chemistry, vol. 77, no. 4, pp. 592-594, 2004. 

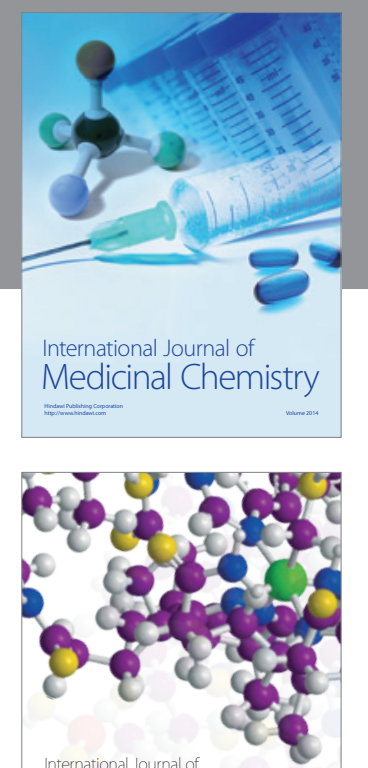

\section{Carbohydrate} Chemistry

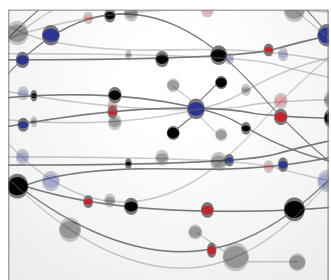

The Scientific World Journal
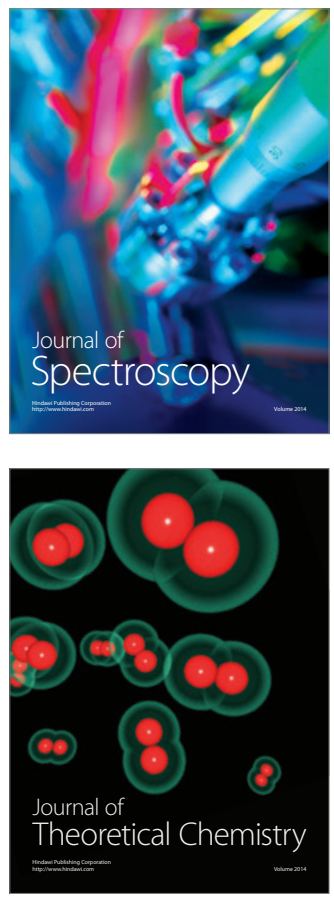
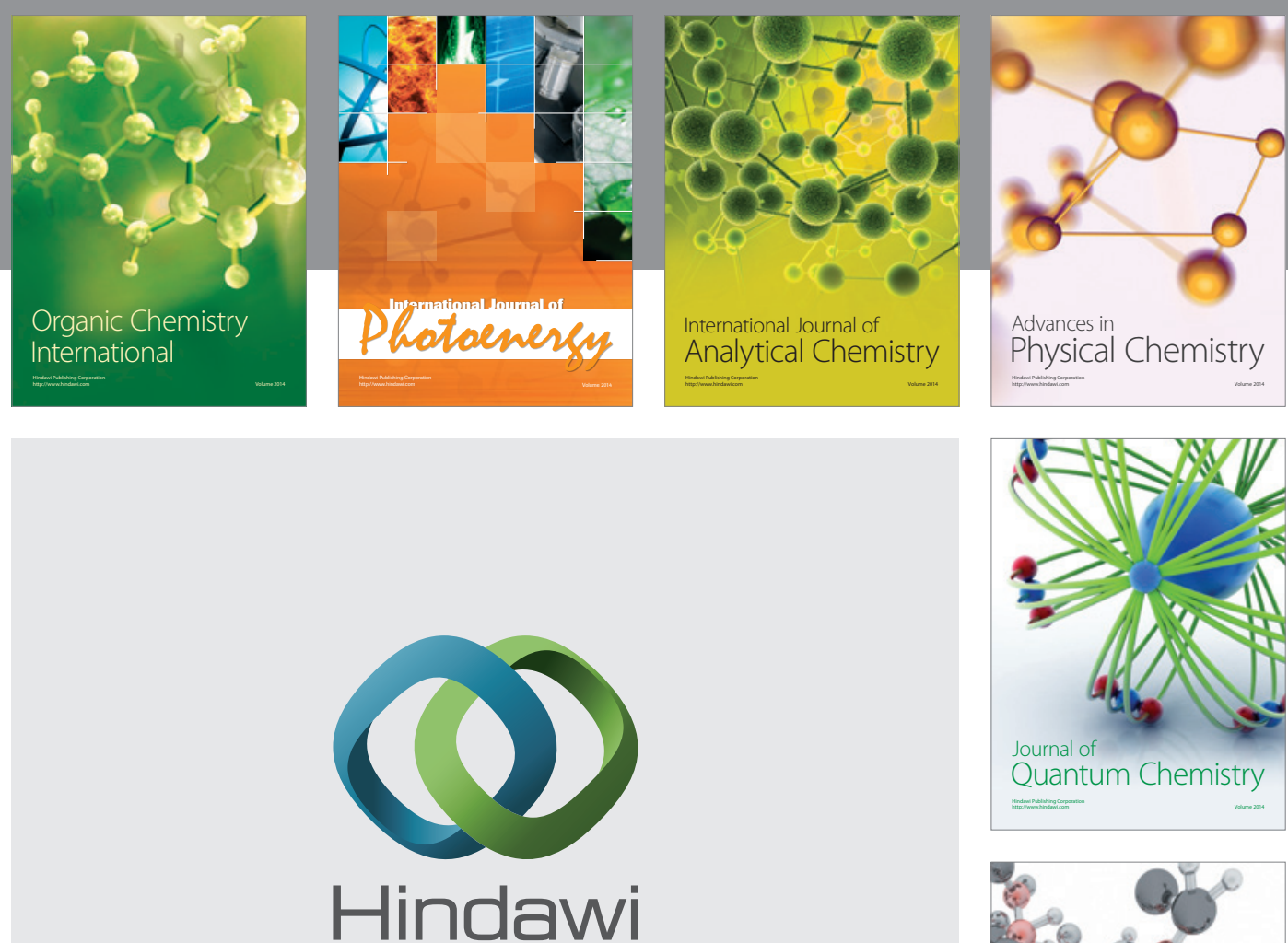

Submit your manuscripts at

http://www.hindawi.com

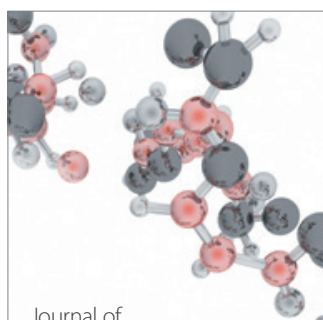

Analytical Methods

in Chemistry

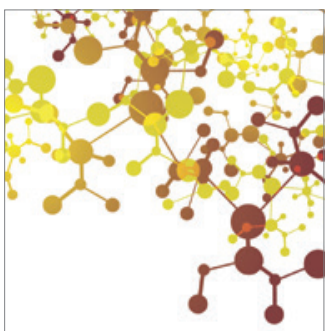

Journal of

Applied Chemistry

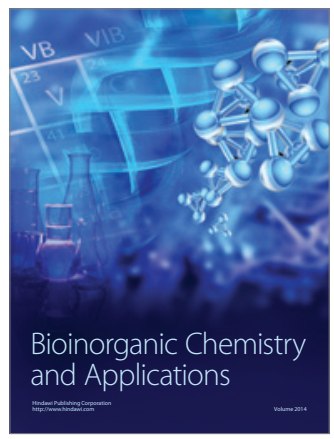

Inorganic Chemistry
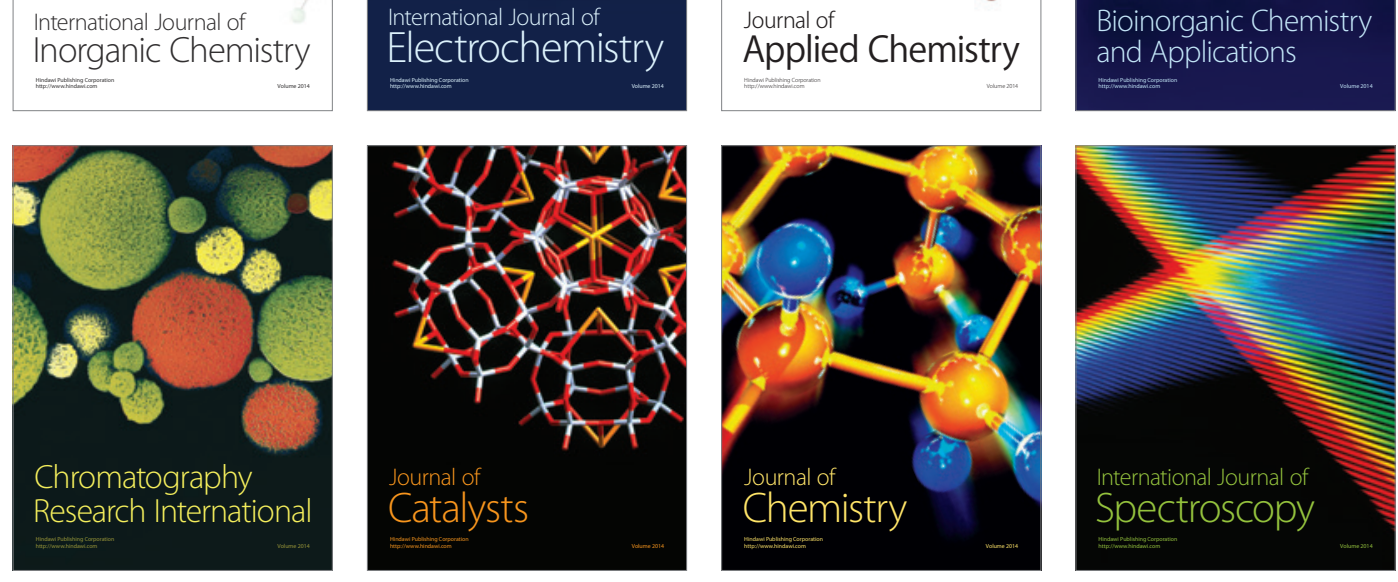